\title{
The Rule of Law for the Right to Inclusive Education in Indonesia
}

\author{
Maya Indrasti Notoprayitno*, Faridah Jali ${ }^{* *}$ \\ DOI: https://doi.org/10.22304/pjih.v6n3.a9
}

Submitted: November 18, 2019 | Accepted: January 27, 2020

\begin{abstract}
Indonesia is committed to guarantee the right to education for all citizens without exception. The commitment of Indonesia to Education for All (EFA) leads to the fulfillment of inclusive education policies. The people of Indonesia tend to understand inclusive education as education for people with disabilities. On the other hand, inclusive education has a broader meaning, which does not refer only to special education. Furthermore, it also covers education with special services. The essence of inclusive education is to remove barriers that limit all marginalized learners, to respect diversity and needs, to create patterns of education without discrimination, and ultimately to achieve quality education. People's understanding leads to questions about inclusive education in legal context, as well as the rules of inclusive education in Indonesia. This paper contains a qualitative study with a historical-doctrinal approach. The study aims to explain the right to inclusive education listed in the rules and regulations in Indonesia and their problems. From the normative point of view, the rules on inclusive education are regulated in the Law Number 8 of 2016 on Persons with Disabilities and the Regulation of the Minister of National Education Number 70 of 2009. Furthermore, the rules of inclusive education can also be found in several other regulations implicitly. Most of the rules have stipulated provisions that include the right to education. Therefore, the Government appears to be progressively realizing the respect, protection, and fulfillment of the right to education, including inclusive education, for all people of Indonesia.
\end{abstract}

Keywords: education for all, inclusive education, right to education

\section{Aturan Hukum Hak atas Pendidikan Inklusif di Indonesia}

\begin{abstract}
Abstrak
Indonesia berkomitmen menjamin hak atas pendidikan bagi seluruh warganya tanpa terkecuali. Komitmen Indonesia terhadap Pendidikan untuk Semua atau Education for All (EFA) membawa pada komitmen dalam pemenuhan kebijakan pendidikan inklusif.

PADJADJARAN Journal of Law Volume 6 Number 3 Year 2019 [ISSN 2460-1543] [e-ISSN 2442-9325]

* Lecturer of International Law, the Faculty of Law, Universitas Trisakti, Jl. Kyai Tapa 1 Grogol Jakarta, S.H. (Faculty of Law, Universitas Trisakti), M.Si. (Faculty of Social and Political Sciences, Universitas Indonesia), Ph.D. Candidate (Faculty of Law, Universiti Kebangsaan Malaysia), maya@trisakti.ac.id

** Lecturer of Public Law, the Faculty of Law, Universiti Kebangsaan Malasysia, 43600 UKM Bangi Selangor, LL.B (Faculty of Law, Universiti Kebangsaan Malaysia) LL.M (Faculty of Law, London University), Ph.D (Faculty of Law, Warwick University), Professor (Faculty of Law, Universiti Kebangsaan Malaysia), faridah@ukm.edu.my
\end{abstract}


Masyarakat Indonesia memiliki kecenderungan memahami pendidikan inklusif sebatas pada pendidikan bagi penyandang disabilitas. Di lain sisi, pendidikan inklusif memiliki makna luas tidak saja dalam konteks pendidikan khusus namun juga pendidikan layanan khusus inti dari pendidikan inklusif adalah untuk menghilangkan hambatan yang membatasi semua peserta didik termarginalkan, menghormati keberagaman dan kebutuhan, sehingga dapat menciptakan pola pendidikan jauh dari diskriminasi, dan pada akhirnya dapat mencapai pendidikan yang berkualitas. Kecenderungan pemahaman masyarakat tersebut membawa pada pertanyaan mengenai pemahaman pendidikan inklusif dalam konteks hukum dan bagaimana aturan pendidikan inklusif di Indonesia. Tulisan ini adalah kualitatif dengan pendekatan doktrinal historis. Tulisan ini bermaksud menjelaskan hak atas pendidikan inklusif yang tercantum dalam aturan-aturan hukum di Indonesia serta permasalahannya. Dari segi normatif, aturan tentang pendidikan inklusif diatur dalam Undang-undang nomor 8 tahun 2016 tentang Penyandang Disabilitas dan Peraturan Menteri Pendidikan Nasional nomor 70 tahun 2009. Namun, secara implisit aturan terkait pendidikan inklusif dalam konteks pendidikan layanan khusus juga dapat ditemukan di beberapa peraturan lain. Aturan-aturan tersebut sebagian besar telah mengatur ketentuan-ketentuan yang dapat mengimplementasikan indikator-indikator hak atas pendidikan. Dengan demikian, Pemerintah nampak secara progresif memenuhi penghormatan, perlindungan dan pemenuhan hak atas pendidikan pendidikan inklusif bagi semua.

Kata Kunci: hak atas pendidikan, pendidikan inklusif, pendidikan untuk semua

\section{A. Introduction}

Education is a basic human right. Every individual has the same right to get an education. However, in several regions of Indonesia, students sometimes find difficulties to access education because of the limited accessibility or availability of schools. Here are some examples of the limitations of access to education. For instance, students in the District of Tompobulu, Maros, South Sulawesi, struggle to go to school because they do not have access to links such as bridges. These students are scattered in several villages, ranging from the Villages of Bonto Matinggi, Bonto Manurung, and Bonto Somba. ${ }^{1}$ Another case, children with disabilities find difficulties to go to school because of the limited numbers of Special Schools (SLB -Sekolah Luar Biasa, Indonesian term) in their areas. For example, there are only four SLBs in West Papua. ${ }^{2}$ In addition, it does not rule out the possibility of children with disabilities in West Papua being scattered in several regions with difficulties. In another case, children of Indonesian migrant workers in

\footnotetext{
1 M. Bakrie, "Hari Pendidikan Nasional 2018, Cerita Perjuangan Keras Anak Pedalaman di Maros Meraih Cita-cita", https://news.detik.com/berita/d-4001024/cerita-perjuangan-keras-anak-pedalaman-di-maros-meraih-citacita, downloaded on October 27, 2019.

2 Kementerian Pendidikan dan Kebudayaan, "Pusat Data dan Statistik Pendidikan dan Kebudayaan, Statistik Sekolah Luar Biasa (SLB) 2016/207", Jakarta, 2017.
} 
Malaysia cannot attend school due to self-documentation barriers. For example, children who follow their parents working in plantations in Sabah, Kinabalu, Malaysia find difficulties to get formal education in Malaysia because the limited ownership of legal documents (birth certificates) or because of high levies to be paid by their parents. ${ }^{3}$ Another case to mention is refugee children, due to either natural disasters or war and children who are in child custody. These children often have difficulties to access education. The examples show that education is relatively difficult to be reached. The conditions may also stigmatize the children as marginalized children. On the contrary, education must be the most important part because it is a fundamental right for every individual.

A good education is an education that can provide, access, reach, and receive students in terms of equality, equity, and quality. The government has committed to uphold human rights. Therefore, the government has affirmative actions that complement the right to equality and non-discrimination for the marginalized people. The affirmative actions are channels for the fulfillment of rights for some vulnerable groups, such as women, disabilities, minorities, or other marginalized people. Affirmative actions can appear under denominations such as "special actions" or "positive actions". 4

Indonesia has formulated regulations related to education. Article 31 of the 1945 Constitution clearly stipulates the right to education as a basic right of the Indonesian people. The right to education is contained in the (1) the Law Number 20 of 2003 on the National Education System; (2) Article 60 of the Law Number 39 of 1999 on Human Rights; (3) Article 10 and Article 40 of the Law on Persons with Disabilities; and (4) Article 9 of the Law Number 35 of 2014 on the Amendments to Law Number 23 of 2002 on Child Protection. In addition, there are still a number of regulations and regulations below, both Government Regulations, Regional Regulations, and Ministerial Regulations governing the right to education. At the international level, the right to education is contained in Article 26 of the Universal Declaration on Human Rights (UDHR), and Article 13 and Article 14 of the International Covenant on Economic, Social, and Cultural Rights (ICESCR), and several other articles of international conventions related to human rights. Article 26 of the UDHR explains that the right to education is recognized as a human right. There is an obligation for guarantees parents to provide the right to education for

\footnotetext{
3 Maya Indrasti Notoprayitno, "Right to Education for Children of Indonesian Migrant Workers", Paper Presented at the INTCESS15 2nd International Conference on Education and Social Sciences, Istanbul - Turkey, 2015, p. 343.

$4 \quad$ Leyla Denisa Obreja, "The Relationship Between Affirmative Action and Equality In The International Human Rights System: A Compatibility Test", Master Thesis International Human Rights Law, Faculty of Law, Lund University, 2015, p. 58.
} 
their children. The state also has responsibility of respecting, protecting, and fulfilling these rights. Article 13 of the ICESCR states as follows.

"Education shall be directed to the full development of the human personality and the sense of its dignity, and shall strengthen the respect for human rights and fundamental freedoms. They further agree that education shall enable all persons to participate effectively in a free society, promote understanding, tolerance and friendship among all nations and all racial, ethnic or religious groups, and further the activities of the United Nations for the maintenance of peace."

Article 1, Paragraph (a), of the UNESCO's Recommendation on Education for International Understanding, Co-operation, and Peace and Education related to Human Rights and Fundamental Freedoms in 1974, reads, "The whole process of social life by which individuals and social groups learn to develop consciously within, and for the benefit of, the national and international community, all their personal capacities, attitude, talents and knowledge".

Education is attached to all individuals so that it is not permissible to implement education in any form of discrimination. The 1960 UNESCO's Convention against Discrimination in Education aims to remove discrimination against differences, exceptions, restrictions or preferences, which are based on races, colors, sexes, languages, religions, political -or other- opinions, national or social origins, and economic or birth conditions affecting the equality of treatment in education (Article 1, Paragraph [1]). Furthermore, Article 1 Paragraph (2) means that the term education means "All types and levels of education, [including] access to education, standards and quality of education, and the conditions under which it is granted". Education teaching can be given in national, provincial, or local education systems, both public and private. "(Indonesia has not ratified this Convention). ${ }^{5}$

The international community understands very well the importance of the right to education as part of a country's development. The World Education Forum held by UNESCO in Dakar in 2000 committed to The Education for All (EFA). EFA intends to provide quality basic education for all children. For this purpose, the EFA contributes to the Sustainable Development Goals (SDG's). SDGs are an agreement with the international community to achieve the target by 2030. The right to education that is expected to be achieved is a fair-and-inclusive education and the achievement of quality educational equality. Thus, the peak of success in fulfilling the right to education is the achievement of "lifelong learning opportunities for all".

Klaus Dieter Beiter, "The Protection of Right to Education by International Law", Leiden: Martinus Nijhoff Publisher, 2005, p. 19. 
The purpose of SDGs is inseparable from the principles of universal human rights. It is indivisible and interdependent, interrelated, equality, and nondiscrimination. Universal means that the right to education applies to all and everywhere without exception. The SDGs Agenda in 2030 ensures that all children can access quality education from early to higher education. The certainty of access to education for all individuals is because the right to education is inseparable and interdependent with other rights. The right to education is part of economic, social, and cultural rights. However, the right to education is also important for the fulfillment of civil and political rights. Reflected by the fulfillment of the right to voice and opinion, the right to be free from slavery, as well as other civil and political rights requires the ability to be able to understand the situation through knowledge, and of course the ability to read, write and count.

The principles of human rights in education are equality and nondiscrimination. ${ }^{6}$ Equality and non-discrimination are pillars in the protection of the right to education. Equality in the right to education means that everyone has equal educational opportunities in society. If school-age children in urban areas have the right to obtain basic education, marginalized school-age children also have the same rights. However, equality needs to go along with equity. Justice is intended that the granting of the right to education to various groups in society be adjusted to the conditions to create equality that applies fairly. Education must be accessed equally and fairly so that all levels of society can enjoy the right to education without exception, including vulnerable or marginalized groups. If children in urban areas have easy access to education, marginalized children must also easily access education. Thus, when the right to education is implemented equally and fairly, there is the principle of non-discrimination that does not discriminate based on race, color, sex, religion, language, nationality and social status, age, disability, or ethnic groups.

Associated with the principle of equality and non-discrimination in education and the development of human rights thinking, the educational service mechanism is increasingly developing to get closer to these human rights principles. Educational service that is currently developing is inclusive education. Inclusive education is close to the motto of the SDGs "Not to Leave Behind". Inclusive education aims to eliminate the limitations and restrictions of all students' participation. Inclusive education respects the different needs of each student so that education for all (EFA) are expected to occur. To that end, the international community including the Indonesian government has issued policies to provide full access to education, including for marginalized students. Problems arise when

Article 1 of the Universal Declaration of Human Rights: "All human beings are born free and equal in dignity and rights". 
people do not understand inclusive education fully as a part of the EFA. When the problem of education accessibility arises as mentioned earlier, the question that arises is whether the government has regulated inclusive education; and what legal rules the government has regulated?

This paper conveys the understanding of inclusive education in Indonesia by referring to the rules related to the inclusive education policies. It provides an understanding of the efforts of the Indonesian government to uphold the right to education by referring to the policy of inclusive education towards education for all (EFA).

\section{B. Right to Education in the Case of Inclusive Education}

The right to education must be applied equality without discrimination to all individuals. There are two categories of acts of discrimination according to Article 2, Paragraph (2), of ICESCR: direct and indirect discriminations. Direct discrimination occurs when a person is treated unpleasantly because laws and policies clearly impede opportunities for specific individuals or groups. Indirect discrimination refers to laws, policies, or practices that appear neutral but have a disproportionate impact on implementation. ${ }^{7}$ Marginalized or vulnerable groups easily experience discrimination. Strictly speaking, law and policy will seek to be non-discriminatory as a form of upholding human rights, but it is possible that law, policy, or program has a disproportionate impact.

In addition to non-discrimination, the right to education must be fair and equitable both procedurally and substantially. Procedural justice is the extent to which all parties, especially those who are left behind, can be involved in the entire development process. On the other hand, substantial justice is the extent to which development policies and programs can, or are able to, answer the problems of citizens, especially disadvantaged groups. ${ }^{8}$ To achieve this principle, the 2030 agenda of the SDGs ensures that all children can complete free, equality, and quality primary and secondary education, which leads to relevant and effective learning outcomes. In addition, the 2030 agenda of the SDGs also seeks to build and improve the quality of education facilities that are sensitive to gender, children, and disabilities and to provide a safe, non-violent, inclusive, and effective learning environment for all.

Inclusive education is an educational service mechanism that can embrace these principles. Inclusive education is important for marginalized students of

General Comment Number 16 on Article 2 of the International Covenant on Economic, Social, and Cultural Rights (ICESCR)

8 Sustainable Development Goals, "Apa itu SDGs", https://www.sdg2030indonesia.org, downloaded on October 27, 2019. 
vulnerable groups -such as children, women, people with disabilities, minority groups. It also includes socially marginalized people such as underprivileged children, child laborers, street children, children in remote areas, child workers migrants, refugees, child victims of war, and so on. Differentiating or sharing education services for marginalized groups has an impact on their ability in social life in society. There are cases related to education for marginalized groups who then provide an understanding of inclusive education, namely the case of Brown v. Board of Education. ${ }^{9}$ The case occurred in 1954 in the United States. The case is a case where a student who was not accepted to attend a regular school because of racial issues. The student is of minority students who are marginalized in regular schools. The case was subsequently brought to court. The United States Supreme Court stipulates that educational facilities be for all without exception. Thus, separate education is not permitted for any reason. The case provides an understanding that education services cannot be compartmentalized. According to Gautier, education is inherent to all individuals, including marginalized and vulnerable individuals. Polat, who says that education should not be separated, expresses the same opinion. Polat gives the argument that the mechanism of educational services that are able to meet the needs of every student without conditions is inclusive because education with an inclusive service mechanism can shape society inclusively. ${ }^{10}$ Gautier and Polat's opinions emphasize that inclusive education can provide answers to the removal of barriers and discrimination for all individuals.

Furthermore, Arnot and Pinson state that inclusive and diversity are important characteristics as a form of good practice in schools. ${ }^{11}$ This opinion is also in accordance with the opinion of Padhi. According to Padhi, diversity in inclusive education can answer the learning needs of all children, especially those who are vulnerable to marginalization and exclusion. ${ }^{12}$ The studies indicate that inclusive education is education for all by removing barriers. Mostly, Indonesian regulations that are related to education mention an understanding of inclusive education for people with disabilities. Firdaus writes that inclusive education is a strategy to

\footnotetext{
9 Gauthier de Beco, "The Right to Inclusive Education According to Article 24 of the UN Convention on The Rights of Persons with Disabilities: Background, Requirements And (Remaining) Questions", Netherlands Quarterly of Human Rights, Vol. 32/3, 2014, http://www.included.eu/sites/default/files/documents/de_beco_nqhr_32.3.pdf., downoaded on 5th December 2016, p.287

10 Filiz Polat, "Inclusion in Eduation: Step Towards Social Justice", Journal of International Educational Development, Vol. 31, No. 1, 2011, p. 51.

11 Taylor, S., and Sidhu, R. K., "Supporting Refugee Students in Schools: What Constitutes Inclusive Education?", International Journal of Inclusive Education, Vol. 16, No. 1, 2012, pp. 39-56.

12 Soubhagya Ranjan Padhi, "Overcoming Exclusion and Marginalization in Education through Inclusive Approaches: Challenges and Vision of Arunachal Pradesh in India", International Journal of Social Science and Humanity, Vol. 6, No. 4, 2016, p. 257.
} 
create schools that are responsive to the needs of the community. He later emphasizes inclusive education for children with disabilities. ${ }^{13}$ Likewise, Hadis explains inclusive education as an access for all children to be able to learn together, wherever possible, regardless of difficulties or differences. For this reason, inclusive education is an equality and equitable educational opportunity for children with special needs or disabilities. ${ }^{14}$

As the right to education develops, UNESCO issues a statement regarding inclusive education. According to UNESCO, inclusive education is conditioned, or intended, for children with disabilities (or special needs), girls, children in remote villages, and very poor people. The UNESCO, in 2009, mentions an understanding of inclusive education as follows. ${ }^{15}$

"Inclusive education is a process of strengthening the capacity of the education system to reach out to all learners ... As an overall principle, it should guide all education policies and practices, starting from the fact that education is a basic human right and the foundation for a more just and equal society."

UNICEF, UNESCO, and UNDP initially declared inclusive education in Thailand through the Jomtien Declaration in 1990. The Jomtien Declaration is the beginning of the United Nations commitment to achieve the EFA. The core of the Declaration is access to education and equal education for all children, ensuring access to and improving the quality of education equitably for all children both underprivileged children, child laborers, street children, children in remote areas or minority groups, persons with disabilities, child workers migrants, refugees, child victims of war, etc. These children must get the right to education free of charge at least at the level of primary education. Inclusive education that removes barriers to accessing education can be done by schools making adjustments in various aspects to be able to adjust to the conditions of students. Now, inclusive education is developing along with the agreement of the international community in committing to EFA. The World Conference on Special Needs Education, known as the Salamanca Statement 1994, also influences this commitment. The Salamanca Statement seems to be clearer in explaining inclusive education for people with disabilities.

\footnotetext{
13 Endis Firdaus, "Pendidikan Inklusif dan Implementasinya di Indonesia", Seminar Nasional Pendidikan, Purwokerto: Universitas Soedirman, 2010.

14 Fawzia Aswin Hadis, "Toward Inclusive, Inclusive Education in Indonesia a Country Report" Paper Presented at Seisa University, Ashibetsu-shi Hokkaido Japan July 9, 2005.

15 UNESCO, Policy Guidelines on Inclusive Education, http://www.inclusive-education-inaction.org/iea/index.php?menuid=36\#i, 2009, downloaded on December 5, 2016, p. 8.
} 
The Salamanca Statement says that every child has a fundamental right to education and must be given the opportunity to achieve and to maintain an acceptable level of learning. Each child has unique characteristics, interests, abilities, and learning needs. The education system must be designed and educational programs implemented to take account of the wide diversity of these characteristics and needs. They who have special educational needs must have access to regular schools that must accommodate them in child-centered pedagogy that is able to meet these needs. ${ }^{16}$ Inclusive education for persons with disabilities or those with special needs is much better understood because inclusive education for persons with disabilities has a different method than inclusive education for other marginalized groups. The removal of educational barriers for persons with disabilities is done by uniting students with disabilities with regular students in regular schools that are inclusive schools. In addition, as explained by Sulaimanov, inclusive education for persons with disabilities is carried out with methods that adapt to the conditions of children through curriculum adaptation, adapted teaching methods, modified assessment techniques, and accessibility arrangements. ${ }^{17}$

A large country with a high heterogeneity of people, the Indonesian government faces complexity in the fulfillment of the right to education. The government's policy on inclusive education is intended to fulfill the right to education for all citizens. The Law Number 20 of 2003 on the National Education System mandates a nine-year compulsory education free of tuition for all Indonesian citizens without exception. This compulsory education consists of elementary school and junior secondary school. In fact, the Indonesian government through the Ministry of Education and Culture has prepared a 12-year compulsory education road map, which means that compulsory education as basic education in Indonesia starts from basic education (elementary school and junior secondary school) to senior secondary school.

\section{Provision of Educational Services}

Various groups generally know inclusive education as a part of the education services for persons with disabilities. Essentially, the reference is much broader. In ICESCR, precisely in General Comment number 13 related to the right to education, it is said that there are four fulfillments of the right to education, and the stateparties of the covenant have obligations related to human rights so that education

16 The Salamanca Statement and Framework for Action on Special Needs Education, Adopted By The World Conference on Special Needs Education: Access And Quality, Salamanca, Spain, June 7-10, 1994.

17 Farid Sulaimanov, "Issues of Inclusive Education: Some Aspects to be Considered", Electronic Journal for Inclusive Education", Vol. 3 No. 4, 2015, p. 6. 
can be fulfilled. The four obligations are availability, accessibility, acceptability, and adaptability. According to Tomasevski, the four indicators of fulfilling the right to education are based on human rights. This is due to the state's obligation to fulfill the right to education, which is the responsibility of the government to uphold human rights. ${ }^{18}$

The availability enables the government to guarantee education without cost and compulsory education for all children. The government must also be able to respect the freedom of parents to choose their children's education. It covers school availability in physical form and learning facilities, such as laboratories, libraries, sanitation, and the availability of teachers. The government is required to provide reasonable accommodation for students. The government must also be able to provide accessibility by promoting the principle of non-discrimination, namely education must be reachable by all, especially for vulnerable groups as mentioned above. In addition, the access in question is also physical access and economic access. Physical access is intended to facilitate reaching schools geographically or technologically. Furthermore, economic access is that basic education is compulsory, so it is free of charge. The next indicator is acceptability, that is, the government guarantees the form and system of education including curriculum and learning methods that can be followed by students so that acceptability is closely related to adaptability. Adaptability is meant that education must be able to adjust the conditions and needs of students, so that students do not adjust to the syllabus or facilities that are already available. This needs to be comprehended in the discussion of inclusive education in inclusive schools.

\section{Regulation on Inclusive Education}

Efforts to implement inclusive education policies are part of the country's obligations in fulfilling economic, social, and cultural rights. Indonesia has ratified ICESCR through the Law Number 11 of 2005. The Article 2 of ICESCR states that the fulfillment of economic, social, and cultural rights is carried out in a progressively sustainable manner. Progressive refers to a positive right, that is, the government has an obligation to actively respect, protect, and fulfill that right. By taking steps in stages but in a short period, including the provision of limited resources. These steps must be carried out in a planned, concrete and directed towards the goals that are formulated as clearly as possible. Resources in fulfilling the right to education, including teachers, are indeed considered still limited in Indonesia, especially for schools in remote areas. However, the government is still obliged to

18 Katarina Tomasevski, "Pendidikan Berbasis Hak Asasi Penyederhanaan Persyaratan Hak Asasi Manusia Global", Proyek Kerja Sama antara Pelapor Khusus Perserikatan Bangsa-Bangsa (PBB) tentang Hak atas Pendidikan dan Biro Pendidikan Wilayah Asia Pasifik UNESCO, p. 57. 
meet the minimum standard requirements to comply with the minimum level of compliance of each of the rights contained in the Covenant. The state is obliged to ensure the fulfillment of the broadest possible rights under these limited conditions and to ensure that the program can protect marginalized groups.

Normatively, the implementation of inclusive education is regulated in various regulations related to education. In other words, regulations related to education are part of the efforts to implement education in an inclusive manner. In several international conventions and declarations related to human rights such as the Convention on the Rights of the Child (CRC), it says that the right of children to obtain education is absolute, and that it is achieved progressively based on equal opportunities. The Convention on the Elimination of All Forms of Discrimination against Women (CEDAW) also emphasizes that equality and equity of the right to education for men and women. The United Nations Declaration on the Rights of Indigenous Peoples (UNDRIP) adopted by the General Assembly of the United Nations on September 13, 2007 also states its attitude towards the principle of non-discrimination in the fulfillment of the right to education. Furthermore, the Convention on the Rights of Persons with Disabilities (CRPD) clearly explains the right to education for persons with disabilities by ensuring a special education system or inclusive education at all levels and lifelong learning. Based on the international conventions, the terminology of inclusive education is only stated in Article 24 of the CRPD. Therefore, inclusive education tends to be comprehended as a part of "special" education for people with disabilities.

The Indonesian government also has granted the right to education for all citizens without exception in accordance with the mandate of the 1945 Constitution. As mentioned earlier, the regulations includes clause on the right to education but, explicitly, inclusive education can be seen in the Law Number 20 years 2003 on the National Education System; the Law Number 8 of 2018 on Persons with Disabilities; the Regulation of the Minister of National Education Number 70 of 2009 on Inclusive Education for Students Who Have Disabilities and Have Potential Intelligence and/or Special needs; the Regulation of the Minister of National Education number 72 of 2013 on Special Services Education that has been updated by the Regulation of the Minister of National Education Number 67 of 2016; and the Regulation of the Minister of Research, Technology and Higher Education Number 46 of 2017 on Special Education and Special Services Education. The latter regulation is set at the level of higher education.

According to Article 32 of the Law Number 20 of 2003, the implementation of inclusive education is carried out through special education and education with special services. The article regulates education for those who have special needs and need special services. 


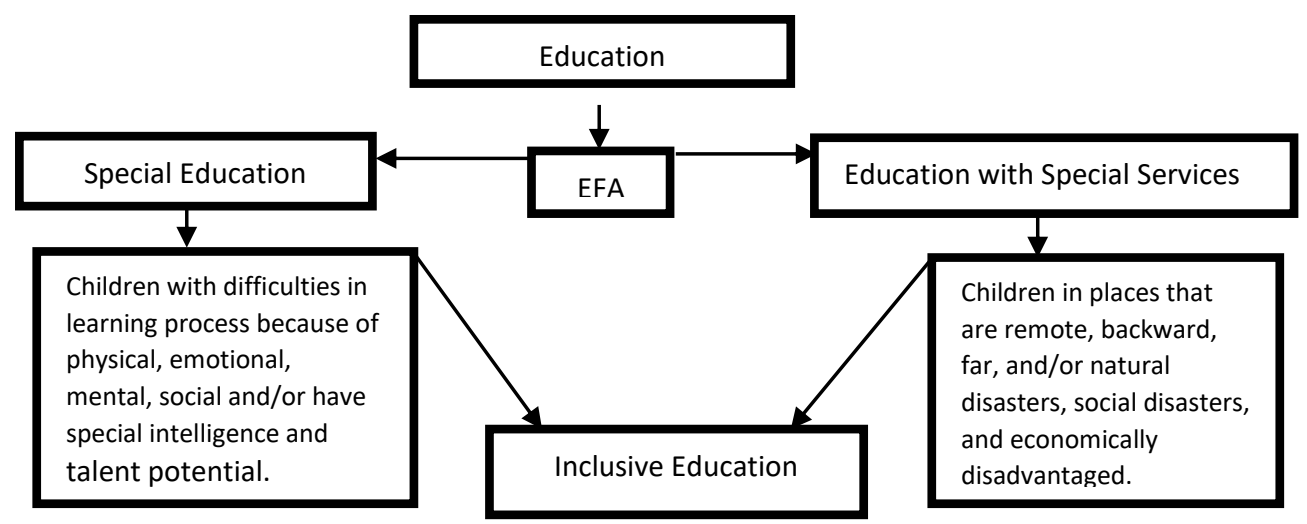

Figure 1.1. Inclusive Education for All

1. Special Education: education for students with difficulties in learning process because of physical, emotional, mental, social and/or have special intelligence and talent potential.

2. Education with Special Services: education for students in places that are remote, backward, far, and/or natural disasters, social disasters, and economically disadvantaged.

\section{E. Special Education}

Special education in Indonesia as explained above is intended for students with special needs. Students with special needs can be categorized as students who have difficulty the learning process physically, emotionally, mentally are children with disabilities. These students include (1) visual impairment, (2) hearing impairment, (3) speech and language disorders or communication disorders, (4) mental retardation/severe disabilities, (5) physical impairment, (6) emotional and behavioral disorders, (7) specific learning disability, (8) slow learner, (9) autism, (10) motoric impairment, (11) another disorder/retardation, and (12) double disorder/retardation. Students who have difficulty in following the learning process due to social factors are students who are victims of drug abuse, illegal drugs, etc. Students who have difficulty in learning process but have the potential for intelligence and special talents are students who have abilities in certain fields, for example athletes or children who have achievements in the arts. ${ }^{19}$

Article 51 of the Law Number 35 of 2014 on the Amendment of the Law Number 23 of 2002 on Child Protection states that children with disabilities are given the opportunity and accessibility to obtain inclusive and/or special education. Article 10 of the Law Number 8 on 2016 on Persons with Disabilities implicitly

19 Article 3 of the Regulation of the Minister of National Education Number 70 of 2009 on Inclusive Education for Students Who Have Disabilities and Have Potential Intelligence and/or Special Talents. 
explains the same thing about the right to education. Education for persons with disabilities can be carried out specifically through special education by organizing Special Schools (SLB) or by inclusion through inclusive education by organizing inclusive schools. Article 40 of the Law Number 8 of 2016 is an article on inclusive education with the terminology of inclusive education as in Article 24 of the CRPD. The article stipulates the obligations of the government and regional governments in implementing inclusive education.

Inclusive education for persons with disabilities has referred to Law number 8 of 2016. At the technical level, inclusive education has been regulated earlier in the Regulation of the Minister of National Education Number 70 of 2009. The Ministerial Regulation was formed earlier than the Law Number 8 of 2016. However, the Ministerial Regulation is still valid as long as there is no substitution. The Regulation of the Minister of National Education Number 70 of 2009 was formed without delegation from the Law number 20 of 2003. Article 32 Paragraph (3) of the Law number 20 of 2003 says that Government Regulation, and not the Ministerial Regulation would regulate the implementation of the provisions for special education and education with special services further. However, the implementation of the provisions of the Ministerial Regulation legally tends to provide problems in implementation, namely when local governments do not fully have the political will in implementing inclusive education for persons with disabilities in their respective regions. In the decentralized system, education is under regional authority. The division of authority for inclusive education in the regions is; for basic education in the regency/city, while for secondary education at the provincial level. With the regional authority in implementing autonomous education, many consider the power of the Ministerial Regulation to be insubstantial. Thus, the Regulation Number 70 of 2009 made by the Ministry of National Education at that time became a polemic when the inclusive education policy for persons with disabilities would be implemented in the regions.

There is a tendency to assume that local governments are not bound by the Ministerial Regulation since there is no sanction if the Ministerial Regulation is not followed by the local government. This has an impact on the implementation of inclusive education for people with disabilities in the regions. The implementation of inclusive education for persons with disabilities is not running optimally if there is no will from the local government. This assumption does not have an appropriate legal basis considering that the Article 8 Paragraph (2) of the Law Number 12 of 2011 on the Formation of Legislation says that there is no difference between statutory and policy of ministerial regulations. Therefore, the position of Ministerial Regulation as policy regulation remains in effect as long as it is not revoked or canceled. Furthermore, Manan and Magnar explain that Ministerial Regulations 
formed without delegation from higher legislation are policy regulation (beleidregels) which indirectly binds the public. ${ }^{20}$

Although the provisions contained in the Regulation of the Ministry of National Education Number 70 of 2009 are still valid, the government is currently working on the establishment of regulations that are more directed towards achieving the four indicators of fulfilling the right to education for persons with disabilities. The government is currently drafting a Government Regulation on Reasonable Accommodation in Inclusive Education for Persons with Disabilities. The Draft of Government Regulation will be in accordance with the mandate of the Law Number 8 of 2016 that adequate accommodation in education will be regulated further through a Government Regulation. The action plan for the preparation of the Draft of Government Regulation is a form of government progressive steps in identifying and removing legal obstacles including of course physical, communication, social, and community attitudes, especially in the regions. The availability of adequate accommodation is the most important part of fulfilling inclusive education for people with disabilities. This is in accordance with the provisions of Article 24 of the CRPD that if there is a violation in the provision of adequate accommodation, it is a form of discrimination that violates the provisions of the law, specifically Article 24 of the CRPD. ${ }^{21}$

Appropriate accommodation in inclusive education for persons with disabilities is part of the implementation of four indicators for the fulfillment of the right to education. The implementation of the four indicators in the provisions of the regulation on the right to education are as follows.

\section{Availability}

The government has guaranteed education without fees and compulsory education for all children. The Law Number 20 of 2003 regulates 9 years of compulsory education. Then, the Law Number 8 of 2016 says 12 years of compulsory education. The application is based on the policies of each local government. Both laws have also paid respect to the freedom of parents to choose their children's education. The law even regulates that persons with disabilities have two forms of schools: special or inclusive schools. The physical availability and facilitation of inclusive education in some inclusive schools is still in a progressive stage considering the needs of students with disabilities are different from regular learners. Therefore, it requires modification. The draft is expected to provide a strong legal basis for the realization of physical availability and facilities to avoid the forms of discrimination

\footnotetext{
20 Bagir Manan dan Kuntana Magnar, "Beberapa Masalah Hukum Tata Negara Indonesia, Bandung: Alumni, 1997, p.169.

21 General Comment Number 4 on Article 24 of the Convention on the Rights of Persons with Disabilities (CRPD)
} 
and violations contained in Article 24 of the CRPD since Indonesia has ratified it by the Law Number 19 of 2011.

\section{Accessibility}

Article 40 Paragraph (4) of the Law Number 8 of 2016 requires Regional Governments to prioritize students with disabilities attending school in locations close to where they live or known as zoning pathways. Therefore, if there is no SLB within the reach of the place of residence of students with disabilities, then regular schools must be able to accept, and even if there are SLBs, these students wish to enter regular schools, then the school has no right to refuse for any reason including reasons lack of decent accommodation. Furthermore, Article 43 Paragraph (3) of the Law Number 8 of 2016 stipulates that schools, which do not provide adequate accommodation for students with disabilities, can be subjected to administrative sanctions. Provision of suitable accommodation can be done in stages but immediately (see Article 2 ICESCR).

\section{Acceptability and Adaptability}

The Government, through the Regulation of the Ministry of National Education Number 70 of 2009 and Law number 8 of 2016 guarantees the form and system of education including curriculum and learning methods. Human resources, both educators and special guidance teachers (GPK - Guru Pembimbing Khusus and/or Guru Pendidikan Khusus, Indonesian term) for students with disabilities are part of efforts to fulfill both indicators (acceptability and adaptability). The Regulation of the Ministry of National Education Number 70 of 2009 regulates teachers, including GPK, but still faces some obstacles in practice. One obstacle is related to the availability of GPK. Generally, a GPK is not a classroom teacher or guidance teacher, but a teacher who has special educational qualifications with capability to handle students with disabilities. GPK are placed in inclusive schools to help deal with children with disabilities. So far, the number of GPK in inclusive schools is still very limited, thus the handling is done by regular teachers which is still limited. ${ }^{22}$ Actually the notion of GPK mentioned above can be traced into two understandings. The first understanding is as stated above that teachers from special education who have qualifications and competencies in the field of special education and are placed in inclusive schools. This teacher is a Special Education Teacher. Whereas the second understanding is the GPK which is a regular teacher who has the additional task of assisting students with special needs in inclusive schools. This teacher does not have a special educational background. The Law Number 8 of 2016 does not regulate in detail related to GPK. However, the government is well aware of issues related to the limitation. Therefore, Article 4

22 Interview with School Principal of SDN Pojok, Sleman, Yogyakarta, January 11, 2018. 
Paragraph (7e) of the Regulation of the Minister of Education and Culture Number 15 of 2018 on the Fulfilling the Workload of Teachers, School Principals, and School Supervisors regulates the existence of additional tasks for regular teachers as GPK at inclusive schools that organizes inclusive education. However, problems still occur related to the absence of regulations regarding the working hours and allowances for GPK with special educational background and regular teacher's competency qualifications as GPK. There are demands for teachers in organizing inclusive education. Teachers in inclusive schools must be able to understand and adjust the conditions of students with disabilities. Teachers must be able to adjust syllabus and learning methods to these students by not forcing students to follow the same material as regular students. This conformity reflects the principle of equality. The principle of equality is related closely to human-rights-based model approach to the understanding of disability-rights approaches. ${ }^{23}$ The human rights model in the context of understanding disability rights sees that persons with disabilities have equal rights and considers that if the principle of equality applies to persons with disabilities, there will be injustice and will result in violations of the law. ${ }^{24}$

\section{F. Education with special services}

In the implementation of education with special services, the government provides educational services with minimum educational standards to students who cannot enjoy good education services. ${ }^{25}$ They consist of students that are marginalized due to geographical or isolated conditions (such as students who live in concentrated and living in disadvantaged areas), students living in remote areas, students living in coastal areas and islands, students living in border areas, students living in a former disaster area, students living in isolated tribes, and students living in uninhabitable communities. In addition, education with special services can be intended for students who experience educational obstacles due to family factors, for instance: students being left by their parents due to migration to other places, students living in conditions where they work illegally, students living on plantations that do not have educational services, students living in prisons because of illegal actions. Finally, students are due to social factors such as

\footnotetext{
23 There are three model approaches in seeing rights for persons with disabilities: medical, social, and human right-based model. The medical model sees disability from a medical perspective, that is, individuals who need medical help and protection, while the social model seeks to provide equal access to persons with disabilities but does not see the need for equality.

24 Sarah Arduin, "Who Says They Are Special? Reflections on Diverse Approaches to Disability, Education And The Law", Doctoral Dissertation, The University of Dublin, 2013.

25 Mudjito, Elfindri, Harizal, Pendidikan Inklusif, Jakarta: Baduose Media, 2012, p. 15.
} 
students being victims of narcotics and former drug users, students living in war and conflict areas, and students facing specific and thematic challenges. ${ }^{26}$

Based on the existing rules related to education with special services, inclusive education by the government can be done in various ways. The implementation of education with special services also refers to four indicators of fulfilling the right to education. All this time, rules relating to education with special services are further regulated in Ministerial Regulations and not yet in drafts. The Regulation of the Minister of National Education Number 72 of 2013 which is amandement by the Regulation of the Minister of National Education Number 67 of 2016 stipulates that education with special services can be formal, non-formal, and informal. Formal education is a structured and tiered education pathway consisting of basic education, secondary education, and higher education. Non-formal education is a channel of education outside of formal education that can be structured and tiered. Informal education is education from family and environment ${ }^{27}$, for example, students in Pangkep Regency, South Sulawesi. Educational services for students carried out on a boat that is usually used for fishing. The teacher teaches on a boat with an independent learning system using student worksheets. This learning process activity is commonly called a boat class. ${ }^{28}$ In general, boat classes are not only conducted in Pangkep Regency but also in several provinces in Indonesia often use the same educational services. The example of education for children of remote tribes is the Talang Mamak tribe in Riau who move around and group in the forest. The Riau Provincial Government has created a Marginal School program called the Learning Kiosk. The marginal school is located between the villages of the Talang Mamak tribe so that children can be able to learn more easily to the marginal school. ${ }^{29}$ Efforts made by the government and the community in providing education services can be done in various ways as mentioned above. The four indicators of fulfilling the right to inclusive education are summarized in the main points of the Regulation of the Minister of Education and Culture Number 67 of 2016 on the Implementation of Education with Special Services.The form of school services as a form of inclusive education is as follows. ${ }^{30}$

\footnotetext{
$26 \quad$ Ibid.

27 Diana, "Pendidikan Formal, Informal", http://st306509.sitekno.com/article/63509/pendidikan-formal-nonformal-dan-informal.html, downloaded on 14th September 2015.

28 Jaringan Inovasi Pelayanan Publik Sulawesi Selatan, http://jipp.sulselprov.go.id/, 2018, Download on March 1, 2019.

29 Roza Irfania, Daeng Ayub Natuna, Widiastuti, "Harapan Suku Talang Mamak Terhadap Pelayanan Pendidikan Di Desa Talang Jerinjing Kecamatan Rengat Barat Kabupaten Indragiri Hulu”, https://media.neliti.com/media/publications/207227-harapan-suku-talang-mamak-terhadap-pelay.pdf, download on March 1, 2019.

30 Ministerial Regulation Number 67 Year 2016 regarding the Implementation of Education with Special Services
} 
1. Small schools provide educational services for a minimum number of three students;

2. Open schools provide visiting-teacher services from their parent schools;

3. Emergency schools provide services in situations of natural and/or social disasters;

4. Integrated schools organize education carried out between levels of education in one location;

5. Schools in other forms are schools located in remote or backward areas, border areas with other countries, areas that have experienced natural disasters, social disasters, or areas that are in other emergencies, and/or outer small islands.

Education with special services does not only reach students in Indonesia but also students of Indonesian citizens who are abroad, especially in Malaysia. These students are children of Indonesian migrant workers who work in Malaysia. Generally, these migrant workers are workers who work in palm fields. Their children cannot go to school because they cannot show their identities such as a child's birth certificate or child's passport or because of expensive private school tuition in Malaysia. The Government, in this case the Ministry of Foreign Affairs in collaboration with the Ministry of Education and Culture, has already made a joint regulation of the two ministries: the Joint Regulation of the Minister of Foreign Affairs and the Minister of Education and Culture Number 7 of 2015 and Number 1 of 2015 on Management and Implementation of Indonesian Education Abroad. The outcome of the agreement was the implementation of the formation of the Indonesian School in Malaysia. There is the Indonesian Schools in Kinabalu, Johor Bahru, and Kuala Lumpur. The latter has been existed far before the Joint Regulation. These schools accommodate Indonesian citizen students from various regions in Indonesia ranging from kindergarten to senior secondary school. For those who are undocumented, there is an opportunity to take education during document preparation. There are non-formal schools established through the collaboration of community institutions and companies in the form of Corporate Social Responsibility (CSR). The schools were established in the area of oil palm plantations. Non-formal schools can help students to further their education to an advanced stage or take the exam in formal schools. Accessibility to get formal education equality can be done by attending Exam Package $A, B$, or C. ${ }^{31}$

Some local governments already have local regulations related to education. This can help the delivery of education, especially inclusive education. Inclusive

31 Exam Package A equivalent for elementary school, B equivalent for junior secondary school, and $\mathrm{C}$ equivalent for senior secondary school. 
education, both special education and education with special services, must still be met by looking at the four indicators of fulfilling the right to education as described previously. That the government has clearly guaranteed compulsory education without fees. The availability of schools in some areas or in remote areas in Indonesia physically is still experiencing problems. Nevertheless, the rules in the Ministerial Regulation provide solutions in the provision of learning as in existing cases, including the provision of adequate accommodation for students with disabilities. This inclusive education fully meets the affordability indicator by promoting the principle of non-discrimination by not differentiating education for each individual. Law guarantees marginalized children to be able to access education. Physically, every student can attend school. If it is difficult to reach school locations both geographically and in available technology, there are still other forms of education services. The same thing is done in inclusive education for people with disabilities. Inclusive education for students with disabilities is adjusted to the needs of students so that they can become one through learning together with other students. Such opinion is in accordance with the opinion of Sulaimonov and Salamanca Statement. Students in remote islands have limitations in reaching the nearest school. Then, the learning system adapts to their circumstances so that students can achieve acceptance and compatibility in learning methods.

There are normative regulations of inclusive education exercised by the government. One of the obstacles that often occur are more to the factor of legal culture and understanding of inclusive education both from local governments and from the communities. The lack of comprehension on inclusive education sometimes has an impact on the implementation in the regions, even though the central government already has regulations. Thus, strengthening inclusive education policies requires full support from the people. Save the Children highlights the importance of three components in the delivery of inclusive education called 'the golden triangle'. ${ }^{32}$ The three components are family, community, and school. In this case, the institution highlights inclusive education for people with disabilities. However, the component is a definite form of promoting inclusive education. In addition to these three components, the government also plays a very important role in the implementation of inclusive education because policies are born from it and the legal rules made also contribute to the implementation of the policy. The family as the main component gives encouragement to students to attend school. Accessibility to education regulated in international rules as well as in Article 7 of the Law Number 20 of 2003 says that parents have the right to play a role in taking part in the selection of

32 Save the Children, “Mainstreaming Inclusive Education, Sharing Good Practice”, 2019, p. 39. 
education for their children. Thus, the role of parents is quite large in education. Community also has a role to play because they can help provide socialization or advocacy both legal and social related to the implementation of inclusive education. Article 8 and 9 of the Law Number 20 of 2003 stipulate the important role of community in the implementation of education. The community has the right to participate in planning, implementation and monitoring, and evaluation of educational programs and must support by providing the resources needed in the implementation of education.

\section{G. Conclusion}

Legal policies related to inclusive education in Indonesia have distanced themselves from forms of discrimination in education, so there is no direct discrimination but tend still found indirect discrimination in the implementation, such as implementation of GPK for example. Respect for the right to education for marginalized students can be done by providing students the opportunity to reach out to education in various ways. Evidence of the government's commitment to protect and fulfill the right to education can be seen in the commitment to uphold economic, social, cultural rights by maximizing the state's full capacity to achieve progressive rights, including the adoption of legal actions. ${ }^{33}$ However, it might be a question of whether such education will be able to provide quality education. As stated above, the education desired by the international community through SDGs is an education that can provide, give access for, reach, and receive students in terms of equality, equity, and quality. Quality education must provide the skills and knowledge. Attitudes and behaviors are required by not only reading, writing, and arithmetic comprehension but also skills for a broader life provision. Inclusive education can provide provision of life in accepting diversity and tolerance for regular students and provision for life in getting to know and socialize for marginalized students. In other words, academic understanding and skills are indeed necessary but students are also required to understand social environment. Both of them can support the continuity of being able to live independently in accordance with the demands of long-life learning.

Understanding contextual inclusive education needs to be comprehended by community as a form of understanding behavior towards students. In general, community will accept the policy when it has been stated in a rule of law or regulation. However, the law merely does not guarantee public understanding of inclusive education. The public will increasingly understand when the policy is truly for social justice, advocacy, and culturally meaningful. The government has

33 Asbjorn Eide and Catarina Krause (ed), "Hak Ekonomi, Sosial dan Budaya”, Leiden: Martinus Nijhoff Publisher, 2001. 
respected the right to education for all through progressive action efforts under the umbrella of legal regulations in the form of laws and technical regulations to protect against educational barriers and discrimination. In fulfilling the right to inclusive education, it does not only rely on the law in substance but also the cultural context of the community in understanding inclusive itself.

\section{References}

\section{Books}

Bagir Manan dan Kuntana Magnar, Beberapa Masalah Hukum Tata Negara Indonesia, Alumni, Bandung, 1997.

Beiter, Klaus Dieter, The Protection of Right to Education by International Law, Martinus Nijhoff Publisher, Leiden, 2005.

Eide, Asbjorn and Catarina Krause (ed)., Hak Ekonomi, Sosial dan Budaya, Martinus Nijhoff Publisher, Leiden, 2001.

Mudjito, Elfindri dan Harizal, Pendidikan Inklusif, Baduose Media, Jakarta, 2012.

\section{Others Documents}

Arduin, Sarah, "Who Says They Are Special? Reflections on Diverse Approaches to Disability, Education And The Law", Doctoral Dissertation, The University of Dublin, 2013.

de Beco, Gauthier "The Right to Inclusive Education According to Article 24 of the UN Convention on The Rights of Persons With Disabilities: Background, Requirements and (Remaining) Questions", Netherlands Quarterly of Human Rights, Vol. 32/3, 2014, http://www.included.eu/sites/default/files/documents/de_beco_nqhr_32.3.pdf., accessed on 5th., downloaded on 16th January 2018.

Diana, "Pendidikan Formal, Non Formal, Informal", http://st306509.sitekno.com/article/63509/pendidikan-formal-nonformal-daninformal.html, downloaded on 14th September 2015.

Endis Firdaus, Pendidikan Inklusif dan Implementasinya di Indonesia, Seminar Nasional Pendidikan, Purwokerto, Universitas Soedirman, 2010.

Fawzia Aswin Hadis, "Toward Inclusive, Inclusive Education in Indonesia a Country Report" Paper Presented at Seisa University, Ashibetsu-shi Hokkaido Japan July 9, 2005.

Interview with School Principal of SDN Pojok, Sleman, Yogyakarta, on January 11, 2018.

Jaringan Inovasi Pelayanan Publik Sulawesi Selatan, http://jipp.sulselprov.go.id/, 2018, downloaded on 1st March 2019.

Kementerian Pendidikan dan Kebudayaan, Pusat Data dan Statistik Pendidikan dan Kebudayaan, Statistik Sekolah Luar Biasa (SLB) 2016/207, Jakarta, 2017. 
M. Bakrie, "Hari Pendidikan Nasional 2018, Cerita Perjuangan Keras Anak Pedalaman di Maros Meraih Cita-cita", https://news.detik.com/berita/d-4001024/ceritaperjuangan-keras-anak-pedalaman-di-maros-meraih-cita-cita, downloaded on 27th of October 2019.

Maya Indrasti Notoprayitno, "Right to Education for Children of Indonesian Migrant Workers", Paper Presented at the INTCESS15 2nd International Conference on Education and Social Sciences, Istanbul - Turkey, 2015.

Obreja, Leyla Denisa, "The Relationship Between Affirmative Action and Equality In The International Human Rights System: A Compatibility Test", Master Thesis, International Human Rights Law, Faculty of Law, Lund University, 2015.

Padhi, Soubhagya Ranjan, "Overcoming Exclusion and Marginalization in Education through Inclusive Approaches: Challenges and Vision of Arunachal Pradesh in India", International Journal of Social Science and Humanity, Vol. 6, No. 4, 2016.

Polat, Filiz, "Inclusion in Eduation: Step Towards Social Justice", Journal of International Educational Development, Vol. 31, No. 1, 2011.

Roza Irfania and Daeng Ayub Natuna, Widiastuti, "Harapan Suku Talang Mamak Terhadap Pelayanan Pendidikan Di Desa Talang Jerinjing Kecamatan Rengat Barat Kabupaten Indragiri Hulu", https://media.neliti.com/media/publications/207227-harapan-suku-talangmamak-terhadap-pelay.pdf, download on 1st March 2019.

Save the Children, "Mainstreaming Inclusive Education, Sharing Good Practice", 2019.

Sulaimanov, Farid, "Issues of Inclusive Education: Some Aspects to be Considered", Electronic Journal for Inclusive Education: Some Aspects to be Considered", Electronic Journal for Inclusive Education, Vol. 3, No. 4, 2015.

Sustainable Development "Apa itu SDGs", https://www.sdg2030indonesia.org, downloaded on 27th of October 2019.

Taylor, S., and Sidhu, R. K., "Supporting refugee students in schools: what constitutes inclusive education?", International Journal of Inclusive Education, Vol. 16, No. 1, 2012.

The Human Right Protection of Vulnerable Groups, www.humanrights.is/thehuman

rights.../humanrightscasesandmaterials/humanrightsconceptsideasandfora/Un dirflokkur/, downloaded on 1st March 2019.

Tomasevski, Katarina, "Pendidikan Berbasis Hak Asasi Penyederhanaan Persyaratan Hak Asasi Manusia Global", Proyek Kerja Sama antara Pelapor Khusus Perserikatan Bangsa-Bangsa (PBB) tentang Hak atas Pendidikan dan Biro Pendidikan Wilayah Asia Pasifik UNESCO.

UNESCO, Policy Guidelines on Inclusive Education, http://www.inclusive-educationin-action.org/iea/index.php?menuid=36\#i, 2009, downloaded on December 5, 2016. 


\section{Legal Documents}

Convention on the Rights of Persons with Disabilities (CRPD)

General Comment Number 16 on Article 2 of the ICESCR

General Comment Number 13 to Article 13 of the ICESCR

General Comment Number 4 on Article 24 of the CRPD

International Covenant on Economic, Social, and Cultural Rights (ICESCR)

Regulation of the Minister of National Education Number 72 of 2013 on the Education with Special Services [Peraturan Menteri Pendidikan Nasional Nomor 72 Tahun 2013 tentang Pendidikan Layanan Khusus]

Regulation of the Minister of National Education Number 67 of 2016 on Education with Special Services [Peraturan Menteri Pendidikan Nasional Nomor 67 Tahun 2016 tentang Pendidikan Layanan Khusus]

Regulation of the Minister of Research, Technology, and Higher Education Number 46 of 2017 on Special Education and Education with Special Services [Peraturan Menteri Riset, Teknologi dan Pendidikan Tinggi No, 46 Tahun 2017 tentang Pendidikan Khusus dan Pendidikan Layanan Khusus]

The Salamanca Statement and Framework for Action on Special Needs Education, Adopted By The World Conference on Special Needs Education: Access And Quality, Salamanca, Spain, 7-10 June 1994.

Universal Declaration on Human Rights. 